\title{
Parental worklessness and the experience of NEET among their offspring. Evidence from the Longitudinal Study of Young People in England (LSYPE)
}

\author{
Ingrid Schoon
}

Institute of Education, University of London

I.Schoon@ioe.ac.uk

(Received December 2013 Revised April 2014)

http://dx.doi.org/10.14301/llcs.v5i2.279

\section{Abstract}

This paper examines the assocations between parental worklessness and the experiences of their offspring making the transition from school to work during a time that included a major economic downturn. The study draws on data collected for the Longitudinal Study of Young People in England (LSYPE), a cohort of young people born in 1989/90 completing compulsory education in 2006 - just before the onset of the Great Recession. Data on parental worklessness collected between 2004 and 2006 was linked to information about subsequent employment activities of their offspring, in particular the experience of not being in education, employment or training (NEET) between 2007 and 2010 (ages 16 to 20 years). Parental worklessness was significantly associated with their sons' and daughters' experience of being NEET for longer periods of time (months spent in NEET). However, much of this association was explained by a number of other socio-economic risks facing these young people and their families (e.g. low parental education level, living in rented accommodation and in highly deprived neighbourhoods). Furthermore, the role of individual agency, in particular educational achievement orientation (EAO) as a potential mediator was examined. Although parental worklessness was associated with lower levels of EAO, especially among young males, the findings also suggest that EAO can serve as a potential resource for young men and women in adverse economic circumstances. The study does not support the assumption of an intergenerational transmission of a 'culture of worklessness' but points to the role of multiple deprivations and lack of local opportunities in shaping the life chances of young people.

Keywords: worklessness, inter-generational, socio-economic resources, achievement orientation, gender

\section{Introduction}

The existing literature suggests that growing up in a workless household can have adverse long-term effects regarding academic and occupational attainment (Ermisch, Francesconi, \& Pevalin, 2004), yet the specific issue of inter-generational transmission of worklessness is less well studied, especially in the UK context (Macmillan, 2010; 2011; 2014). Furthermore, there is relatively little understanding of the processes linking the transmission of worklessness from one generation to the next. Indeed the idea that worklessness can be in part explained through familial transmission of values and practices has been called into question (Shildrick, MacDonald, Furlong, Roden, \& Crow, 2012). The aims of this paper are to: a. examine the inter-generational link between parental worklessness and a young person's likelihood of being Not in Education, Employment or Training (NEET) during a time that included a major economic downturn; b. examine gender differences in the association; and c. assess the role of achievement orientations as a potential mediating mechanism, focusing in particular on educational 
aspirations and expectations of young people growing up with workless parents. Drawing on evidence collected for the Longitudinal Study of Young People in England (LSYPE), employment experiences of young people are assessed between ages 16 to 20, after the completion of compulsory schooling, using evidence from a general population sample. The study is guided by a developmental-contextual perspective (Schoon, 2006; Vondraceck, Lerner, \& Schulenberg, 1986; Vondracek, 1998), informed by ecological approaches to human development (Bronfenbrenner, 1986; Elder, 1998) that emphasize multiple interacting influences embedded in a wider sociohistorical context.

\section{School-to-work transitions in times of economic downturn}

The effects of an economic recession are felt most keenly by young people embarking on the transition to adult life (Ashton \& Bynner, 2011; Jenkins, Brandolini, Micklewright, \& Nolan, 2013). Even if the most critical phase of the recession has passed, there can be long-term and lasting consequences, raising the spectre of a 'lost generation'. Recessionary times are likely to limit employment prospects, and lead to less successful transitions to adulthood (Vuolo, Staff, \& Mortimer, 2012). In England and the rest of the UK, the number of young people who are out of work has risen between 2008 and 2011 to its highest level on record (ONS, 2012) and currently one in five people aged 16 to 24 years are looking for work.

In this paper the association between growing up with workless parents and the likelihood of experiencing NEET among their offspring is assessed, as well as gender differences in this association, which are largely ignored in current debates (European Parliament, 2013). The crisis has worsened labour market conditions especially for young men, since male-oriented sectors, in particular manufacturing and construction, were hit first and hardest by the economic slow-down. In the UK the unemployment rate among young males is currently higher than among females, as is the rate of NEET (ONS, 2012). The experience of NEET can be considered as a more comprehensive indicator of hardship than the unemployment rate, as it includes those young people who do not have a job, are not enrolled in training, or are not classified as a student.

\section{Inter-generational transmission of worklessness}

The existing literature suggests that growing up in a jobless household can have adverse long-term effects (Ermisch et al. 2004), and has been found to be associated with lower levels of later educational and occupational attainment (McLanahan \& Sandefur, 1994; Haveman \& Wolfe, 1994; Kiernan, 1997; Schoon et al., 2012) and persistent dependence on social security benefits (Gottschalk, 1996; lacovou \& Berthoud, 2000; Such \& Walker, 2002). As adults, children growing up in poor or workless households are more likely to be workless or poor themselves, as compared to children who grow up in households where someone is employed (Gregg, Harkness \& Machin, 1999; Such \& Walker, 2002). Likewise, evidence on the experiences of children growing up in workless households across Europe suggests that parents' labour market status strongly predicts children's economic well-being, and that children living in households with no employed adults are particularly vulnerable to the experience of income poverty (Harkonen, 2011).

With rising unemployment rates there is now increasing concern about generations of families who have never worked (Coelli, Green, \& Warburton, 2007; Ermisch et al., 2004; Gregg \& Wadsworth, 2008; Harkonen, 2011; Pemberton, 2008; Platt, 2010) and about the potential scarring effects of household worklessness on the future labour market experiences of contemporary children (Macmillan, 2010; 2011). The United Kingdom has an above average proportion of adults living in workless households compared to the European Union, and also a higher proportion of dependent children living in workless households (European Commission, 2014). Thirteen percent of households with dependent children were workless in the second quarter of 2011, which equates to just over one million workless households with dependent children (ONS, 2011). The question of inter-generational transmission of worklessness is thus obviously of high importance.

There is some evidence that worklessness is transmitted inter-generationally (see Macmillan (2010) for a review), although most studies focused on the transmission from father to son. For example, in the UK context, evidence from the 1958 National Child Development Study (NCDS) suggests that $19 \%$ of 
sons who experienced a year or more out of work between the ages 23-33 had had a father out of work at age 16 , compared to the sample average of $10 \%$ (Johnson \& Reed, 1996; see also O'Neill \& Sweetman , 1998). Macmillan (2010) examined the magnitude of the inter-generational correlation of worklessness using the NCDS and the 1970 British Cohort Study (BCS) and found sons were over twice as likely to experience workless spells themselves if they came from a family where the father experienced worklessness during their childhood. Furthermore, the relationship remained strong, even after controlling for a range of family background characteristics, and the inter-generational correlation in worklessness appears to have increased for the later-born cohort. There is also evidence to suggest that the inter-generational effect depends on conditions of the local labour market, i.e. that it is stronger in labour markets with high unemployment rates (Macmillan, 2011, 2014).

The association between parental worklessness and young peoples' experience of NEET has also been confirmed in a recent study using LSYPE (Schoon et al., 2012), although gender differences in this association were not examined. Furthermore, there is little evidence regarding the processes that link parental worklessness to young people's outcomes. The motivation for this research is therefore to obtain a better understanding of gender differences in the association between parental worklessness and the likelihood that a young person will experience NEET, and to gain a better understanding of potential mediating processes and confounders.

\section{Educational achievement orientation (EAO) as a potential mediator}

The level of educational qualifications is particularly important in influencing the probability of being NEET, especially among women. Those with higher level qualifications are less likely to experience NEET, or are NEET for a shorter duration (Crawford, Duckworth, Vignoles, \& Wyness, 2011). One aim of this study is therefore to assess the role of EAO as a potential mediating process. Is there a significant association between parental worklessness and the EAO of young people? Is the impact of parental worklessness on the employment experiences of their offspring mediated by the child's expression of educational optimism and expectations to participate in higher education?

The importance of educational aspirations as a powerful mediator of the effects of parental socioeconomic status on career progression and attainment is well established. Traditional status attainment research has shown that parents of higher socio-economic status have higher aspirations for their children, which are associated with higher aspirations among their offspring (Sewell \& Hauser, 1975; Sewell, Hauser, \& Wolf, 1980). High child aspirations, in turn, are associated with later academic and career success - a finding which has been consistently confirmed in different cultural and historical contexts (Beal \& Crockett, 2010; Johnson \& Reynolds, 2013; Kerckhoff, 1993; Kerckhoff, 2001; Schoon \& Parsons, 2002; Sewell, Haller, \& Ohlendorf, 1970) and for men and women (Mello, 2008; Schoon, Martin, \& Ross, 2007; Sewell, Hauser, \& Wolf, 1980). Furthermore, future-oriented aspirations can reduce the detrimental effect of parental socio-economic hardship and can be an important resource for young people from disadvantaged backgrounds to achieve against the odds (Schoon, 2006).

There is little understanding of the role of EAOs in the inter-generational transmission of worklessness. Furthermore, educational aspirations and expectations have generally increased considerably in recent years (Reynolds \& Pemberton, 2001; Schneider \& Stevenson, 1999), especially among women (Reynolds \& Burge, 2008; Schoon, 2010). Previous evidence also suggests that young males are more susceptible to their parent's socio-economic situation than females, and that socio-economic hardship is associated with lower aspirations among males than females (Schoon et al., 2007; see also Mortimer, Zhang, Hussemann \& Chen-Yu, this volume). Generally the mechanisms linking parental worklessness to their children's outcomes are not well understood. A recent review of the evidence in the UK contexts suggests that there is little evidence to suggest that 'cultures of worklessness' are passed down the generations via low education and work related values (Shildrick et al., 2012). Nonetheless raising aspirations of young people and involvement in higher education have been identified as ways of addressing inter-generational issues in the trans- 
mission of worklessness (Pemberton, 2008), and the role of EAO will thus be examined in this study.

\section{Confounding factors}

There is a fundamental concern that the estimated effects of parental worklessness might be spurious, due to the association with other problematic circumstances (Ermisch et al., 2004; Schoon et al., 2012). It is therefore necessary to take into account potential confounders. In particular, this analysis will control for characteristics of the family, the wider social context, as well as characteristics of the young person, including ethnic background and previous academic attainment.

Factors considered here include sociodemographic family characteristics, family structure, housing conditions, and health, as well as area deprivation (Haveman \& Wolfe, 1994; lacovou \& Berthoud, 2000; McLanahan, 1997, 2004). Parental worklessness is increasingly concentrated in certain subgroups of the population and in certain geographic areas (Gregg \& Wadsworth, 2001; Macmillan, 2014). For example, single adult households are far more likely to be workless than households with two adults (both with and without children), and workless households are significantly more likely to experience poverty than households in which at least one adult is employed (ONS, 2011). Comparing poverty rates of children in jobless households in Europe, Harkonen (2011) found that in the UK and Ireland these were higher than the average in other countries, reaching above $50 \%$. Furthermore, disability strongly affects work rates (Berthoud, 2011), and worklessness is more prevalent in urban areas and the North of England (Webster, 2000). Hence it is important to allow for these other risk factors when modelling the relationship between parental worklessness and outcomes.

Socio-economic family hardship, characterised by worklessness, low income, low levels of education, lone parenthood, large families living in rented accommodation, and parental ill health, create a context that affects young people's development and adjustment. There is consistent evidence on the harmful effects of growing up in circumstances in which families are unable to provide the experiences, resources and services that are crucial for young people to thrive (Bradley \& Corwyn, 2002; Bradshaw
\& Mayhew, 2005; Engle \& Black, 2008). Moreover, previous research suggests that where one lives matters, in terms of quality of family life and life opportunities. Living in a disadvantaged neighbourhood, especially in urban areas, has been associated with lower levels of academic performance and EAO (Ainsworth, 2002; Brooks-Gunn, Duncan, \& Aber, 1997; Jencks \& Mayer, 1990; Murry, Berkel, GaylordHarden, Copeland-Linder \& Nation, 2011).

Certainly the existing evidence suggests that the relationship between any single risk factor and subsequent outcomes tends to be weak. Usually many risks are involved in determining an outcome, and serious risk emanates from the accumulation of risk factors (Garmezy, 1991; Rutter, 1981, 2009). The analysis will thus control for a number of potentially interlinked risk factors (such as family demographics, household income, family structure, parental health, home ownership and number of siblings living in the household, as well as area deprivation) that might explain the association between parental worklessness and the experience of NEET among their offspring. Furthermore, individual factors that have been shown to be associated with EAO of young people are taken into account, in particular the young person's ethnicity and previous academic attainment. Previous academic attainment has been shown to influence the education aspirations and expectations of young people and those of their parents (Gutman, Schoon \& Sabates, 2012; Marjoribanks, 1989; Schoon, 2010). Furthermore, in the current UK context, young people from ethnic minority background express higher educational aspirations than whites (Gutman et al., 2012; Strand, 2007, 2008), which has been attributed to differences in cultural attitudes towards higher education (Torgerson et al., 2008).

Moreover, the analysis will take into account the duration of parental worklessness. Most previous studies have conceptualised worklessness as a state, without taking into account that households may be moving in and out of worklessness over time. This study thus adds to previous research by assessing the relationship between repeated (or persistent) versus temporary parental worklessness, differentiating between families who never experienced worklessness during the period of observation, those who moved in and out of worklessness, and those who were persistently workless at several (at least three) 
subsequent years of observation. Furthermore, the duration of NEET experienced by young people is taken into account, examining the number of months spent in NEET between ages 16 to 20 (between September 2006 and May 2010).

\section{Research questions and hypotheses}

Based on previous evidence this study is guided by four hypotheses:

1. Parental worklessness, in particular the repeated experience of worklessness, increases the likelihood that their offspring will experience NEET for longer periods. This association is expected to hold even after controlling for the confounding factors.

2. Given the lack of prior research evidence regarding gender differences in the association between parental worklessness and NEET, no assumptions about the direction of the effects are specified.

3. It is assumed that the effect of parental worklessness on young people's experience of NEET is mediated by the EAO of the young person, i.e. their aspirations and expectations regarding participation in higher education.

4. As there is little evidence on gender differences in the role of aspirations as mediators between parental worklessness and employment experiences of their offspring, no assumptions about the direction of effects are specified. In contemporary cohorts women have higher education aspirations than men, especially young women from less privileged backgrounds compared to men in similar circumstances (Schoon, 2010). Thus, EAOs could play a stronger role for women, although the effect of achievement orientation on outcomes could be diluted when more women have high ambitions.

The study will contribute to the literature in multiple ways: first, experiences of a current cohort of young people are examined to assess the extent of inter-generational transmission of worklessness; second, gender differences in the association between parental worklessness and the long-term experience of NEET are assessed; third, the role of EAO as potential mediators of this association is tested; fourth, longitudinal data is used to examine the duration of parental worklessness as well as the experience of NEET among young people; and fifth, a number of confounding factors are taken into account in assessing the independent effects of parental worklessness on EAOs and employment outcomes.

\section{Method}

\section{Data}

The study is based on data collected for the Longitudinal Study of Young People in England (LSYPE). LSYPE is a panel study of 15,770 young people born between $1^{\text {st }}$ September 1989 and $31^{\text {st }}$ August 1990. Sample members were all young people in school year 9 (age 14) or equivalent, in England in February 2004. LSYPE oversampled ethnic minorities and special design weights are used in the analysis (for more details see

https://www.education.gov.uk/ilsype/workspaces/pu blic/wiki/Welcome).

Annual face-to-face interviews have been conducted with young people and their parents since 2004, and linkage is available to other administrative data, such as the National Pupil Database (NPD), which includes national assessments for all children in England. From LSYPE, information from Wave 1 to Wave 7 of the dataset was used, covering ages 14 to 20 years. From NPD, a national assessment given at age 11 is used as an indicator of previous academic performance.

\section{Analytic sample}

As all longitudinal studies, LSYPE experienced sample loss between the multiple waves. The analytic sample used for this study comprises individuals with complete data on parental worklessness and own employment histories between ages 16 to 20 . This provided a sample of 5137 males and 4742 females. The sample is largely representative of the original sample, although there is some greater socioeconomic disadvantage among young people who did not continue in the study. Special sample weights, which are calculated and available from the LSYPE website, were applied to account for differential selection probabilities and non-response bias. 


\section{Measures}

\section{Parental worklessness}

Information on parental employment status was collected annually between 2004 and 2006. Parental worklessness was assessed at the household level (not the individual level). Analyses using individual level data on unemployment rather than household data on worklessness have reached very different conclusions, even when using the same sources of information (Gregg \& Wadsworth, 2001). For example, while individual workless rates have fallen over the last twenty years, household workless rates have not, suggesting growing inequality in the distribution of work across households.

A workless family was defined as a family in which no parent living in the household was working at the time the family was interviewed (comprising those who were looking for work, as well as those who were economically inactive, not looking for work because of health problems, disability, or looking after the family). It was only considered whether or not the parents in the household were working. There may have been other employed individuals in the household, such as grandparents or older siblings.

Using the data longitudinally allowed us to identify families where parents:

- were never workless at any of the three assessment points (continuously working)

- moved in and out of worklessness (temporary worklessness)

- were workless over the three (LSYPE) assessment points (persistent worklessness).

It cannot be assumed that the families that were identified as persistent workless were indeed workless throughout the whole period under consideration as the families were not observed continuously and there might have been some fluctuation in family and household circumstances. The discussion of persistent worklessness is therefore subject to this caveat.

\section{NEET}

Information on young people's activity status between ages 16-20 years is based on monthly activity history data collected as part of the study. The measure of NEET used in this paper thus gives an indication of the total number of months in NEET between ages 16 to 20 (September 2006 to May 2010). It can range from 0 to 45 months.

\section{Family demographics}

Parental education. Information on mother's and father's highest educational level were gathered at Wave1, and were coded into six categories using the National Vocational Qualification (NVQ) levels: 1= no qualifications; 2 = qualifications at level 1 , equivalent to five GCSEs ${ }^{i}$ at grades $D$ to $G ; 3=$ qualifications at level 2, equivalent to seven GCSEs at grades $A$ to $C ; 4=$ qualifications at level 3 , equivalent to three and a half $A$ levels which enables access to University; $5=$ higher qualifications not at degree level; $6=$ degree level qualifications. The highest level of either parent was used in the analysis, following the dominance approach (Erikson, 1984). Lone parent family. Measured at Wave1 in the LSYPE, this variable is coded as 1 if the young person lives in a lone parent family and 0 if two parents are present. Teen parent. This variable is coded 1 if the cohort member was born to a teen mother and 0 otherwise. Home ownership in Wave 1 is coded as 1 if the family owns their own home and 0 if they are renting. Number of siblings comprises a measure of how many siblings the young person has. Gross household income was reported by the main parent at wave 1 . The banded information was dichotomised to differentiate between those in the lowest income group (less than $£ 10,400$ per annum) against others. Long standing illness or disability in the family was reported by the parent at wave 1 and is coded 1 if either parent reported a long standing illness or disability and 0 if not.

Area characteristics. The Index of Multiple Deprivation (IMD) was measured at wave 1 to provide a relative measure of deprivation at the small area level across England. The IMD is made up of seven constituent domains comprising income, employment, education, crime, health deprivation and disability; barriers to housing and services deprivation; and living environment deprivation (for more details see http://data.gov.uk/dataset/index-of-multiple-

deprivation ). Areas are ranked from least deprived to most deprived, on an overall composite measure of multiple deprivation. Another source of geographic information is the urban/rural classification in LSYPE, a measure developed by the Department for Environment Food and Rural Affairs (Collingwood et al., 2010). 
Rurality of an area was coded as 0 , contrasting it to urban areas or towns coded as 1 . Information on rurality and multiple area deprivation provide important contextual information regarding the communities that study members are growing up in.

\section{Characteristics of the Young Person}

Ethnicity. The ethnicity of the adolescent was coded as (0) white, versus (1) other ethnic groups. Given the ethnic diversity in England, the different ethnic groups were too numerous and the number of each group was too small to examine differences among the groups individually in our model.

Academic performance at age 11 . Academic performance was calculated using a latent variable comprising maths, english and science scores in national curriculum tests given at the end of Key Stage 2 (i.e., age 11) ii.

Educational Achievement Orientation (EAO). An EOA measure was created, comprising 3 indicators of educational aspirations and expectations. The young people were asked, in Wave 3, whether they wanted to stay on in post-compulsory schooling. YP wants to stay on post-16 is coded 1 when the individual plans to stay on and 0 when they intend to leave. The young people were also asked about their intention to apply for university and the likelihood of getting into university if they apply. Both questions were coded on a 4-point scale with response options 1=very likely, 2=likely, 3=not likely, and 4 =not at all likely. The three items were combined into a measure of EAO using principal component analysis, and saving the factor score for further analysis. The internal consistency of the 3-item scale is satisfactory $(\alpha=.70)$ and the three items load well on one underlying dimension (ranging from .61 for higher education aspiration, .87 for intention to apply for university and .85 for the likelihood to be accepted) explaining about $63 \%$ of the variance. A higher score indicates higher levels of EAO.

\section{Statistical analysis}

All analyses were carried out using the software packages SPSS20 and STATA12. Separate models were run for males and females following the assumption that EAO and NEET are experienced differently by men and women. To test our assumptions stepwise OLS regression models were used to assess the independent effects of parental worklessness, additional socio-demographic factors, and individual characteristics. Gender differences were assessed using $\mathrm{X}^{2}$ - tests, $\mathrm{t}$-tests and differences between slopes tests.To account for missingness in the data, multiple imputation was applied. STATA 12 implements chained equations (MICE) which can handle variables of different measurement types. It is a principled, simulation-based approach for analyzing incomplete data. The objective is not to predict missing values as close as possible to the true ones, but to handle missing data in a manner that results in valid statistical inference, correcting for measurement error in the data (Royston, Carlin, \& White, 2009; Rubin, 1996). Twenty data sets were imputed for the analytic sample. The estimates from the imputed datasets are combined, or pooled, to generate a single set of estimates.

\section{Results}

Table 1 gives the descriptive statistics for all the measures used in the study. The majority of young people grew up in a working household, about $5 \%$ experienced temporary worklessness of their parents, and about $10 \%$ experienced persistent worklessness over the three observation points 2004-2006. There were no gender differences in the frequencies of the demographic variables. Females, however, had higher levels of academic attainment at age $11(p<.001)$, their EAO was higher than that of boys $(p<.001)$, and they experienced fewer months NEET than males $(p<.001)$. 
Table 1. Descriptive statistics (weighted)

\begin{tabular}{|c|c|c|c|c|}
\hline & $\begin{array}{c}\text { Males } \\
(n=5,137)\end{array}$ & $\begin{array}{r}\text { Females } \\
(n=4,742)\end{array}$ & $\begin{array}{c}\text { All } \\
n=9,879)\end{array}$ & $\begin{array}{c}\text { Gender } \\
\text { differences }\end{array}$ \\
\hline Parental worklessness & & & & n.s. \\
\hline Always working & 85.9 & 86.0 & 85.9 & \\
\hline Temporary worklessness & 4.8 & 5.7 & 5.2 & \\
\hline Persistent worklessness & 9.3 & 8.3 & 8.8 & \\
\hline \multicolumn{5}{|l|}{ Additional Risk Factors } \\
\hline Parental education & & & & n.s. \\
\hline NCQ5 (degree level) & 19.9 & 19.8 & 19.8 & \\
\hline $\begin{array}{l}\text { NVQ4 (higher education-but below } \\
\text { degree level) }\end{array}$ & 17.5 & 17.6 & 17.6 & \\
\hline NVQ3 (A-level) & 18.5 & 18.9 & 18.7 & \\
\hline NVQ2 (GCSE -level) & 26.3 & 26.4 & 26.4 & \\
\hline NVQ1 (some qualifications) & 7.7 & 7.7 & 7.7 & \\
\hline No qualifications & 10.1 & 9.5 & 9.8 & \\
\hline Teenaged mother at birth & 5.8 & 5.4 & 5.6 & n.s. \\
\hline Single parent household & 21.1 & 21.7 & 21.4 & n.s. \\
\hline Number of siblings (none) & 14.0 & 14.2 & 14.1 & n.s. \\
\hline 1 & 45.4 & 45.1 & 45.3 & \\
\hline 2 & 25.9 & 26.6 & 26.2 & \\
\hline $3+$ & 14.7 & 14.1 & 14.4 & \\
\hline Home ownership & 77.4 & 78.2 & 77.8 & n.s. \\
\hline \multicolumn{5}{|l|}{ Gross household income } \\
\hline Less than $£ 10,400$ & 13.8 & 14.4 & 14.1 & n.s. \\
\hline Long-standing illness/disability in the family & 19.0 & 19.5 & 19.2 & n.s. \\
\hline Urban/rural & 88.7 & 87.9 & 88.3 & n.s \\
\hline IMD (mean) & 20.8 & 20.5 & 20.6 & n.s. \\
\hline \multicolumn{5}{|l|}{ Characteristics of Young Person } \\
\hline YP ethnicity minority & 10.6 & 11.0 & 10.8 & n.s. \\
\hline $\begin{array}{l}\text { Previous academic attainment at KS2 } \\
\text { (age 11), mean [std]) }\end{array}$ & $\begin{array}{l}26.92 \\
{[4.33]}\end{array}$ & $\begin{array}{l}27.30 \\
{[3.98]}\end{array}$ & $\begin{array}{l}27.11 \\
{[4.17]}\end{array}$ & $p<.001$ \\
\hline EAO (age 16, mean [std]) & $\begin{array}{c}-.24 \\
{[1.10]}\end{array}$ & $\begin{array}{l}.06 \\
{[.92]}\end{array}$ & $\begin{array}{c}.10 \\
{[1.03]}\end{array}$ & $\mathrm{p}<.000$ \\
\hline \multicolumn{5}{|l|}{ NEET } \\
\hline $\begin{array}{l}\text { NEET Total months (Sept } 2006 \text { to May } \\
\text { 2010) - mean [std] }\end{array}$ & $\begin{array}{c}3.5 \\
{[7.25]}\end{array}$ & $\begin{array}{c}3.1 \\
{[7.28]}\end{array}$ & $\begin{array}{c}3.3 \\
{[7.26]}\end{array}$ & $p<.003$ \\
\hline
\end{tabular}

Note. YP indicates Young Person; IMD indicates Index of Multiple Deprivation; KS2 indicates Key Stage 2; and $E A O$ indicates Educational Achievement Orientation. 


\section{The association between parental worklessness} and young people's EAO

Stepwise OLS regression models were used to assess the direct association between parental worklessness and EAO (Model 1). In a next step the sociodemographic confounders were added to the model (Model 2) to assess the independent association between parental worklessness and EAO, over and above the control variables. Model 3 then included the individual characteristics: ethnicity and previous academic attainment at age 11 (Key Stage 2). Model 4 adds interaction terms between temporary and persistent worklessness and academic attainment at age 11.

Table 2 presents the OLS unstandardized coefficients and standard errors for males. Model 1 in Table 2 shows that parental worklessness had a significant main effect on EAO. Both temporary and persistent parental worklessness are associated with reduced levels of EAO. Adding the control variables to the model considerably reduced the association between parental worklessness and EAO, and for males only the association between persistent worklessness and EAO remained significant (Model 2). The findings suggest that much of the association between parental worklessness and achievement motivation (in particular regarding temporary worklessness) can be explained by the sociodemographic family characteristics included in the model. There were independent risk effects from low parental education (less than degree level education), having a young mother and many siblings. Home ownership, higher levels of household income and living in an urban area were associated with higher levels of achievement motivation. Model 3 added the individual level variables, which also showed independent effects: young men from ethnic minority backgrounds expressed higher EAO than white males, as did males who performed well in the Key Stage 2 assessments. Independent risk effects in Model 3 are apparent for low levels of parental education and household income. Adding the individual level variables led to a change in sign of the association between parental worklessness and EAO, suggesting a statistical suppression. That is, it is likely that parental worklessness is associated with poorer academic attainment, which would reduce EAO. Maybe children of workless parents recognize the value of higher education to avoid their parents' plight and aim high regarding their own education participation.

Adding interaction terms between temporary and persistent parental worklessness and previous academic attainment to the model (Model 4), provides further information about the inter-relations of academic achievement and worklessness. In this specification, the coefficient for previous academic attainment indicates its effect for the reference group, always working: .116 $(p<.05)$. The interaction terms represent the differences between this academic achievement effect and that for children of the temporarily workless and persistently workless respectively. For example, for children of persistently workless parents, the effect of academic achievement is $.056(.116-.060=.056)$. Thus, children from persistently, as well as temporarily workless families would still benefit from high levels of achievement regarding their EAO, but not as much as those from working families.

Table 3 presents the OLS unstandardized coefficients and standard errors for females, using the same modelling strategy as above. Model 1 in Table 3 shows that parental worklessness had a significant main effect on EAO. Both temporary and persistent parental worklessness are associated with reduced levels of EAO. Adding the control variables to the model considerably reduced the association between parental worklessness and EAO, and only the association between temporary worklessness and EAO remained significant (Model 2). There were independent risk effects from low parental education (less than degree level education) and having many siblings. Home ownership was associated with higher levels of achievement motivation. Model 3 added the individual level variables, which also showed independent effects: young females from ethnic minority background expressed higher EAO than white females, as did females who performed well in the Key Stage 2 assessments. In Model 3, only parental education and home ownership retained significant independent effects. For females the interaction terms between temporary and persistent parental worklessness and previous academic attainment were also significant (Model 4), suggesting a similar pattern as for males, i.e., the benefit of high academic achievement regarding EAO is significant, yet reduced under conditions of worklessness. 
Table 2. Predicting young person's EAO - MALES (unstandardised OLS regression coefficients)

\begin{tabular}{|c|c|c|c|c|}
\hline & $\begin{array}{c}\text { Model } 1 \\
\text { Coefficient } \\
\text { (Std. Error) }\end{array}$ & $\begin{array}{l}\text { Model } 2 \\
\text { Coefficient } \\
\text { (Std. Error) }\end{array}$ & $\begin{array}{l}\text { Model } 3 \\
\text { Coefficient } \\
\text { (Std. Error) }\end{array}$ & $\begin{array}{l}\text { Model } 4 \\
\text { Coefficient } \\
\text { (Std. Error) }\end{array}$ \\
\hline \multicolumn{5}{|l|}{ Parental worklessness } \\
\hline \multicolumn{5}{|l|}{ Always working (ref) } \\
\hline Temporary worklessness & $-.375 *(.077)$ & $-.026(.089)$ & $.032(.087)$ & $.985^{*}(.391)$ \\
\hline Persistent worklessness & $-.365 *(.051)$ & $-.213 *(.072)$ & $.277 *(.068)$ & $1.739 *(.274)$ \\
\hline \multicolumn{5}{|l|}{ Additional Risk Factors } \\
\hline \multicolumn{5}{|l|}{ Parental education } \\
\hline \multicolumn{5}{|l|}{ NCQ5 (degree =ref) } \\
\hline NVQ4 & & $-.546 *(.051)$ & $-.356 *(.047)$ & $-.343 *(.047)$ \\
\hline NVQ3 & & $-.772 *(.054)$ & $-.540 *(.049)$ & $-.519 *(.049)$ \\
\hline NVQ2 & & $-.905 *(.048)$ & $-.591 *(.046)$ & $-.567 *(.047)$ \\
\hline NVQ1 & & $-1.153 *(.077)$ & $-.722 *(.076)$ & $-.697 *(.076)$ \\
\hline No qualifications & & $-.835 *(.072)$ & $-.516 *(.071)$ & $-.524 *(.070)$ \\
\hline Teenaged mother at birth & & $-.288 *(.077)$ & -.149 (.079) & $-.157 \$(.079)$ \\
\hline Single parent household & & $-.059(.051)$ & $-.063(.048)$ & $-.062(.047)$ \\
\hline Number of siblings & & $-.036 \#(.017)$ & $-.030 \quad(.017)$ & $-.028(.017)$ \\
\hline Home Ownership & & $.183^{*}(.052)$ & $.075(.049)$ & $.077(.049)$ \\
\hline Gross household income & & $.035 \#(.012)$ & $.023 \$(.011)$ & $.021(.011)$ \\
\hline LS illness/disability in the family & & $-.083(.050)$ & $-.072(.046)$ & $-.067(.046)$ \\
\hline Urban/rural & & $.127 \#(.059)$ & $.093(.054)$ & $.087(.054)$ \\
\hline IMD & & $-.001(.001)$ & $-.000(.001)$ & $-.000(.001)$ \\
\hline \multicolumn{5}{|l|}{$\begin{array}{l}\text { Characteristics of Young } \\
\text { Person }\end{array}$} \\
\hline YP ethnicity minority & & & $.692 *(.038)$ & $.703 *(.038)$ \\
\hline $\begin{array}{l}\text { Previous academic attainment } \\
\text { (KS2) }\end{array}$ & & & $.107 *(.004)$ & $.116 *(.004)$ \\
\hline $\begin{array}{l}\text { Temporary worklessness } \times \text { KS2 } \\
\text { achievement }\end{array}$ & & & & $-.038 \#(.016)$ \\
\hline $\begin{array}{l}\text { Persistent worklessness } \times \text { KS2 } \\
\text { achievement }\end{array}$ & & & & $-.060 *(.011)$ \\
\hline Constant & $-.191 *(.018)$ & $.096(.097)$ & $-2.956 *(.154)$ & $-3.232 *(.164)$ \\
\hline $\mathbf{R}^{2}$ & .01 & .15 & .31 & .31 \\
\hline
\end{tabular}

Note. ${ }^{*} p<.001 ; \# p<.01 ; \$ p<.05$. An interaction term between parental worklessness and Key Stage 2 achievement was introduced into this model to test the moderating role of earlier achievement for different levels of parental worklessness. YP indicates Young Person; IMD indicates Index of Multiple Deprivation; KS2 indicates Key Stage 2; and EAO indicates Educational Achievement Orientation. 
Table 3. Predicting young person's EAO - FEMALES (unstandardised OLS regression coefficients)

\begin{tabular}{|c|c|c|c|c|}
\hline & $\begin{array}{c}\text { Model } 1 \\
\text { Coefficient } \\
\text { (Standard Error) }\end{array}$ & $\begin{array}{c}\text { Model } 2 \\
\text { Coefficient } \\
\text { (Standard Error) }\end{array}$ & $\begin{array}{c}\text { Model } 3 \\
\text { Coefficient } \\
\text { (Standard Error) }\end{array}$ & $\begin{array}{c}\text { Model } 4 \\
\text { Coefficient } \\
\text { (Standard. Error) }\end{array}$ \\
\hline \multicolumn{5}{|l|}{ Parental worklessness } \\
\hline \multicolumn{5}{|l|}{ Always working (ref) } \\
\hline Temporary worklessness & $-.406 *(.072)$ & $-.163 \$(.078)$ & $-.145(.077)$ & $.724(.376)$ \\
\hline Persistent worklessness & $-.304 *(.052)$ & $-.032(.074)$ & $-.002(.069)$ & $.746 \#(.289)$ \\
\hline \multicolumn{5}{|l|}{ Additional Risk Factors } \\
\hline \multicolumn{5}{|l|}{ Parental education } \\
\hline \multicolumn{5}{|l|}{ NCQ5 (degree =ref) } \\
\hline NVQ4 & & $-.305 *(.043)$ & $-.186 *(.040)$ & $-.179 *(.040)$ \\
\hline NVQ3 & & $-.503 *(.045)$ & $-.307 *(.042)$ & $-.298 *(.042)$ \\
\hline NVQ2 & & $-.638 *(.043)$ & $-.379 *(.041)$ & $-.366 *(.041)$ \\
\hline NVQ1 & & $-.717 *(.069)$ & $-.360 *(.066)$ & $-.356 *(.066)$ \\
\hline No qualifications & & $-.639 *(.070)$ & $-.404 *(.068)$ & $-.404 *(.067)$ \\
\hline Teenaged mother at birth & & $-.029(.076)$ & $.001(.072)$ & $-.004(.071)$ \\
\hline Single parent household & & $-.011(.046)$ & $-.037(.043)$ & $-.029(.043)$ \\
\hline Number of siblings & & $-.042 \#(.016)$ & $-.023(.015)$ & $-.024(.015)$ \\
\hline Home Ownership & & $.232 *(.049)$ & $.115 \#(.046)$ & $.114 \#(.046)$ \\
\hline Gross household income & & $.011(.011)$ & $-.003(.010)$ & $-.003(.010)$ \\
\hline LS illness/disability in the family & & $-.034(.040)$ & $.027(.036)$ & $.026(.036)$ \\
\hline Urban/rural & & $-.056(.044)$ & $-.073(.040)$ & $-.075(.040)$ \\
\hline IMD & & $-.001(.001)$ & $-.001(.001)$ & $-.001(.001)$ \\
\hline \multicolumn{5}{|l|}{$\begin{array}{l}\text { Characteristics of Young } \\
\text { Person }\end{array}$} \\
\hline YP ethnicity minority & & & $.541 *(.035)$ & $.546 *(.035)$ \\
\hline $\begin{array}{l}\text { Previous academic attainment } \\
\text { (KS2) }\end{array}$ & & & $.094 *(.004)$ & $.099 *(.004)$ \\
\hline $\begin{array}{l}\text { Temporary worklessness } \times \mathrm{KS} 2 \\
\text { achievement }\end{array}$ & & & & $-.034 \$(.015)$ \\
\hline $\begin{array}{l}\text { Persistent worklessness } \times \text { KS2 } \\
\text { achievement }\end{array}$ & & & & $-.030 *(.011)$ \\
\hline Constant & $.111 *(.016)$ & $.378 *(.083)$ & $-2.290 *(.136)$ & $-2.956 *(.154)$ \\
\hline $\mathbf{R}^{2}$ & .02 & .11 & .28 & .28 \\
\hline
\end{tabular}

Note. ${ }^{*} p<.001 ; \# p<.01 ; \$ p<.05$. As in the model for males, an interaction term between parental worklessness and Key Stage 2 achievement was introduced into this model. YP indicates Young Person; IMD indicates Index of Multiple Deprivation; KS2 indicates Key Stage 2; and EAO indicates Educational Achievement Orientation. 


\section{The association between parental worklessness and NEET}

Next, the association between parental worklessness and experience of NEET (number of months NEET between September 2006 and May 2010) among young males and females is assessed in a stepwise OLS regression, as above. Model 1 gives the direct associations between parental worklessness and the total number of months the young person has experienced NEET. Model 2 adds the socio-demographic controls, and Model 3 adds characteristics of the individual (ethnicity, previous academic attainment, and EAO at age 16), and Model 4 adds the interaction terms between parental worklessness and EAO to assess their combined effects on the experience of NEET.

Table 4 presents the OLS unstandardized coefficients and standard errors for males. Model 1 in Table 4 shows that parental worklessness had a significant main effect for the young males being NEET. Both temporary and persistent parental worklessness were associated with an increased number of months in NEET. The average total number of months NEET for males growing up with persistently workless parents was 7.60 , for males with temporary workless parents it was 6.01 months, and for males with parents who were always working it was 2.97 months. Adding the control variables to the model considerably reduced the association between parental worklessness and the experience of NEET. For males, only the association between persistent worklessness and NEET remained significant (Model 2). Furthermore there were independent risk effects from low parental education (in particular where parents had no qualifications), growing up in a single parent household, living in an urban area, or an area with a high level of multiple deprivation. Home ownership was associated with being fewer months NEET. Model 3 added the individual level variables, which also showed an independent effect: young men from ethnic minority background experienced fewer month being NEET, as did those who did well in their Key Stage 2 examination and who expressed higher levels of EAO at age 16. Among the sociodemographic control variables in Model 3, growing up with a single parent, living in rented accommodation, an urban area or an area with high levels of multiple deprivation maintained significant independent risk effects. In Model 4 the interaction terms were added, suggesting that there was a significant interaction between persistent parental worklessness and EAO. The significant coefficient $(b=-2.209, p<.000)$ indicates that young men from persistently workless families who maintained a positive EAO were experiencing fewer months NEET. With increasing levels of EAO the risk of NEET among young people growing up in a workless household is significantly reduced. Furthermore, adding the interaction term reduced the direct association between parental worklessness and NEET to non-significance. There remain significant independent risk effects from growing up in a single parent household, lack of home ownership, living in an urban area or an area with high levels of multiple deprivation. There was no significant interaction between temporary parental worklessness and EAO.

The results for females are presented in Table 5. Model 1 in Table 5 shows that parental worklessness had a significant main effect for being NEET. Both temporary and persistent parental worklessness were associated with an increased number of months in NEET. The average number of months NEET for females growing up with persistently workless parents was 6.62, for females with temporary workless parents it was 6.37 months, and for females with parents who were always working it was 2.50 months. Adding the control variables to the model considerably reduced the association between parental worklessness and the experience of NEET. For females, only the association between temporary worklessness and NEET remained significant (Model 2). There were independent risk effects from low parental education, growing up with many siblings, lack of home ownership and living in an area with a high level of multiple deprivation. Model 3 added the individual level variables, which also showed independent effects: young women from ethnic minority background experienced fewer month being NEET, as did those who did well in their Key Stage 2 examination and who expressed higher levels of EAO at age 16. Among the socio-demographic control variables in Model 3, living in rented accommodation, or an area with high levels of multiple deprivation maintained significant independent risk effects. 
Table 4. Predicting experience of NEET (number of months) - MALES (unstandardised OLS regression coefficients)

\begin{tabular}{|c|c|c|c|c|}
\hline & $\begin{array}{l}\text { Model } 1 \\
\text { Coefficient } \\
\text { (Std. Error) }\end{array}$ & $\begin{array}{c}\text { Model } 2 \\
\text { Coefficient } \\
\text { (Std. Error) }\end{array}$ & $\begin{array}{l}\text { Model } 3 \\
\text { Coefficient } \\
\text { (Std. Error) }\end{array}$ & $\begin{array}{l}\text { Model } 4 \\
\text { Coefficient } \\
\text { (Std. Error) }\end{array}$ \\
\hline \multicolumn{5}{|l|}{ Parental worklessness } \\
\hline \multicolumn{5}{|l|}{ Always working (ref) } \\
\hline Temporary worklessness & $3.043 *(.596)$ & $1.077(.713)$ & $.781(.694)$ & $.123(.536)$ \\
\hline Persistent worklessness & $4.631 *(.574)$ & $1.465 \$(.720)$ & $1.781 \#(.717)$ & $.637(.660)$ \\
\hline \multicolumn{5}{|l|}{ Additional risk factors } \\
\hline \multicolumn{5}{|l|}{ Parental education } \\
\hline \multicolumn{5}{|l|}{ NCQ5 (degree =ref) } \\
\hline NVQ4 & & $.220(.308)$ & $-.542(.309)$ & $-.432(.308)$ \\
\hline NVQ3 & & $.472(.321)$ & $-.645(.328)$ & $-.497(.326)$ \\
\hline NVQ2 & & $.755 \#(.306)$ & $-.600 \quad(.316)$ & $-.404(.315)$ \\
\hline NVQ1 & & $.993(.532)$ & $-.679 \quad(.543)$ & $-.472(.544)$ \\
\hline No qualifications & & $2.507^{*}(.618)$ & $.951(.603)$ & $1.103(.603)$ \\
\hline Teenaged mother at birth & & $.484(.635)$ & $.417(.654)$ & $.272(.655)$ \\
\hline Single parent household & & $.994 \#(.373)$ & $.882 \#(.361)$ & $.825 \#(.361)$ \\
\hline Number of siblings & & $.106 \quad(.123)$ & $.025 \quad(.123)$ & $.045 \quad(.124)$ \\
\hline Home Ownership & & $-1.441^{*}(.396)$ & $-.875 \#(.389)$ & $-.821 \$(.388)$ \\
\hline Gross household income & & $-.025(.087)$ & $.017(.083)$ & $.009(.082)$ \\
\hline LS illness/disability in the family & & $.481(.366)$ & $.381(.364)$ & $.408(.361)$ \\
\hline Urban/rural & & $.763 \#(.269)$ & $.859 \#(.281)$ & $.849 \#(.278)$ \\
\hline IMD & & $.027 \#(.009)$ & $.026 \#(.009)$ & $.026 \#(.009)$ \\
\hline \multicolumn{5}{|l|}{ Characteristics of young person } \\
\hline YP ethnicity minority & & & $-.884 \#(.341)$ & $-.662 \$(.335)$ \\
\hline $\begin{array}{l}\text { Previous academic attainment } \\
\text { (KS2) }\end{array}$ & & & $-.172 *(.038)$ & $-.170 *(.038)$ \\
\hline YP EAO & & & $-.971 *(.136)$ & $-.753^{*}(.138)$ \\
\hline Temporary worklessness x EAO & & & & $-1.165(.612)$ \\
\hline Persistent worklessness x EAO & & & & $-2.209 *(.577)$ \\
\hline Constant & $2.970 *(.106)$ & $2.140 *(.635)$ & $7.008 *(1.274)$ & $6.887 *(1.261)$ \\
\hline $\mathbf{R}^{2}$ & .04 & .07 & .11 & .12 \\
\hline
\end{tabular}

Note: ${ }^{*} p<.001 ; \# p<.01 ; \$ p<.05$. An interaction term between parental worklessness and EAO was introduced into this model to test its potential moderating role for different levels of parental worklessness. YP indicates Young Person; IMD indicates Index of Multiple Deprivation; KS2 indicates Key Stage 2; and EAO indicates Educational Achievement Orientation. 
Table 5. Predicting experience of NEET (number of months) - FEMALES (unstandardised OLS regression coefficients)

\begin{tabular}{|c|c|c|c|c|}
\hline & $\begin{array}{c}\text { Model } 1 \\
\text { Coefficient } \\
\text { (Std. Error) }\end{array}$ & $\begin{array}{c}\text { Model } 2 \\
\text { Coefficient } \\
\text { (Std. Error) }\end{array}$ & $\begin{array}{c}\text { Model } 3 \\
\text { Coefficient } \\
\text { (Std. Error) }\end{array}$ & $\begin{array}{c}\text { Model } 4 \\
\text { Coefficient } \\
\text { (Std. Error) }\end{array}$ \\
\hline \multicolumn{5}{|l|}{ Parental worklessness } \\
\hline \multicolumn{5}{|l|}{ Always working (ref) } \\
\hline Temporary worklessness & $3.873 *(.741)$ & 1.987\# (.768) & $1.510 \$(.753)$ & $1.063(.647)$ \\
\hline Persistent worklessness & $4.126 * .565)$ & $1.229 \quad(.705)$ & $1.333(.705)$ & $.699(.655)$ \\
\hline \multicolumn{5}{|l|}{ Additional risk factors } \\
\hline \multicolumn{5}{|l|}{ Parental education } \\
\hline \multicolumn{5}{|l|}{ NCQ5 (degree =ref) } \\
\hline NVQ4 & & $.004(.307)$ & $-.739 \#(.309)$ & $-.650 \#(.307)$ \\
\hline NVQ3 & & $-.220(.297)$ & $-1.476 *(.311)$ & $-1.355 *(.308)$ \\
\hline NVQ2 & & $.338 \quad(.324)$ & $-1.186 *(.334)$ & $-1.059 *(.332)$ \\
\hline NVQ1 & & 1.765\# (.709) & $-.177 \quad(.677)$ & $-.126(.670)$ \\
\hline No qualifications & & 1.673\# (.651) & $.014 \quad(.632)$ & $.159(.626)$ \\
\hline Teenaged mother at birth & & $-.444 \quad(.640)$ & $-1.047 \quad(.594)$ & $-1.089(.593)$ \\
\hline Single parent household & & $-.131(.366)$ & $-.015 \quad(.359)$ & $-.040 \quad(.353)$ \\
\hline Number of siblings & & $.301 \#(.136)$ & $.180(.136)$ & $.192(.135)$ \\
\hline Home Ownership) & & $-1.751 *(.436)$ & $-1.288 \#(.437)$ & $-1.266 \#(.437)$ \\
\hline Gross household income & & $-.030(.091)$ & $.027 \quad(.087)$ & $.021 \quad(.086)$ \\
\hline LS illness/disability in the family & & $.621(.364)$ & $.476 \quad(.356)$ & $.482 \quad(.353)$ \\
\hline Urban/rural & & $.441(.335)$ & $.444 \quad(.337)$ & $.458 \quad(.334)$ \\
\hline IMD & & $.032 \#(.010)$ & $.033^{*}(.010)$ & $.033 *(.010)$ \\
\hline \multicolumn{5}{|l|}{ Characteristics of young person } \\
\hline YP ethnicity minority & & & $-.921 \#(.319)$ & $-.683 \#(.318)$ \\
\hline Previous academic attainment (KS2) & & & $-.235^{*}(.045)$ & $-.241 *(.045)$ \\
\hline YP EAO & & & $-1.286 *(.180)$ & $-.945 *(.175)$ \\
\hline Temporary worklessness x EAO & & & & $-1.772(.922)$ \\
\hline Persistent worklessness x EAO & & & & $-2.414 *(.650)$ \\
\hline Constant & $2.496 *(.112)$ & $2.351 *(.689)$ & $9.640 *(1.426)$ & $9.61 *(1.411)$ \\
\hline $\mathbf{R}^{2}$ & .04 & .07 & .13 & .14 \\
\hline
\end{tabular}

Note. ${ }^{*} p<.001 ; \# p<.01 ; \$ p<.05$. An interaction term between parental worklessness and EAO was introduced into this model to test its potential moderating role for different levels of parental worklessness. YP indicates Young Person; IMD indicates Index of Multiple Deprivation; KS2 indicates Key Stage 2; and EAO indicates Educational Achievement Orientation. 
Parental education was also significant, although the effects are not monotonic, suggesting that after taking into account individual level characteristics, medium level parental qualifications are associated with reduced time in NEET. In Model 4, the interaction terms were added, suggesting that there was a significant interaction between persistent parental worklessness and EAO. The significant coefficient $(b=-.-2.414, p<.000)$ indicates that young women from persistently workless families who maintained a positive educational achievement motivation were experiencing fewer months of NEET. Furthermore, as for males, adding the interaction term reduced the direct association between parental worklessness and NEET to non-significance. There remain significant independent effects of parental education, housing tenure, and living in an area with high levels of multiple deprivation. There was no significant interaction between temporary parental worklessness and EAO.

\section{Gender differences}

In a final step, gender differences in the association between parental worklessness and EAO and the experience of NEET were tested through a differences between slopes test. Regarding the results for the final model (Model 4 ) in the prediction of EAO, there were significant gender differences for gender and persisting parental worklessness $(t=2.60$; $p<.01)$, parental education at NVQ4 level $(t=260$; $p<.01)$, at NVQ3 level $(t=3.42 ; p<.00)$, NVQ2 level $(t=3.22 ; p<.00)$ and NVQ1 ( $t=3.39 ; p<.00) ;$ urban/rural $(t-2.41 ; p<.02)$, ethnic minority status $(t=3.04 ; p<.00)$, and previous academic attainment at Key Stage 2 $(t=3.00 ; p<3.00)$. Similar patterns are observed for Model 2-3. In Model 1 and 2 however, there are no significant gender differences regarding the experience of parental worklessness. The findings suggest that males living with persistent workless parents, those living in urban areas, those with ethnic minority status, and those who achieved high key stage 2 scores report higher levels of EAO than females in similar circumstances, while boys with less than degree level educated parents report lower EAO than girls in similar circumstances, except for those whose parents have no qualifications at all.

Regarding the experience of NEET, significant gender differences are only found for living with a single parent $(t=2.15 ; P<.03$ in Model 2; $t=1.76 ; P<.08$ in Model 3: and $t=1.71 ; P<.09$ in Model 4 ), suggesting that boys growing up with a single parent are slightly more likely to be NEET than females in similar circumstances.

\section{Discussion}

Before the Great Recession, about one in ten young people in England grew up with persistently workless parents and one in twenty experienced temporary worklessness of their parents. Worklessness has been defined at the household level, focusing on families in which no parent living in the household was employed. Parental worklessness showed a significant direct association with lower levels of EAO among the offspring as well as a prolonged experience of being NEET between ages 16 to 20 when the UK experienced a major economic downturn. The magnitude of the direct effect of parental worklessness on the experience of NEET among the offspring was moderate and explained only a small amount of variance, which suggests that there might be other potential explanatory factors. Furthermore, the association between parental worklessness and the outcomes under consideration could largely be explained by a number of other socio-demographic factors, in particular low levels of parental education, lack of home ownership, large family size and living in an area characterised by multiple levels of deprivation, pointing towards the role of multiple disadvantage and deprivation rather than worklessness per se.

The association between parental worklessness and the young person being NEET was fully explained after taking into account the interplay of worklessness and EAO. There was a significant interaction between parental worklessness and EAO, where young people growing up in persistent workless households, who expressed high levels of EAO, had a reduced risk of experiencing NEET, after taking into account the potential confounding sociodemographic risk factors and individual characteristics. As suggested in a previous qualitative study (Shildrick et al., 2012), the findings thus do not support the assumption of an inter-generational transmission of 'a culture of worklessness', where values and practices that discourage achievement are passed down from parents to their children. Rather, 
the findings suggest that children of workless parents potentially recognize the value of higher education and do not want to repeat the predicament of their parents. Indeed, the majority of young people growing up in workless households aspire to participate in higher education and many want to apply to university. For example, about $75 \%$ of males growing up in workless families want to continue in education beyond compulsory school leaving age, compared to $82 \%$ of males whose parents were always working. For females, the equivalent percentages are $91 \%$ of girls in workless households compared to $93 \%$ of girls with working parents. Aspirations towards studying at university were expressed by $42 \%$ of males and $58 \%$ of females in workless households, compared to $61 \%$ of males and $72 \%$ of females with working parents.

Regarding EAO, low parental education was a significant independent risk factor diminishing the EAO for both males and females over and above the other variables included in the model.

Regarding the experience of NEET, living in rented accommodation, and living in a highly deprived area were independent risk factors for both males and females, over and above the experience of parental worklessness, other socio-demographic factors and individual characteristics (ethnicity, previous academic attainment and EAO), suggesting the importance of how and where one lives in influencing the experience of NEET (Ainsworth, 2002).

Even though males and females differed regarding the time they were NEET, no significant gender differences in the role of socio-demographic, individual and community factors were found, except that for young males, living with a single parent appears to be an additional independent risk factor for experiencing NEET. This finding potentially points to the lack of economic resources and social networks that can undermine the life chances of young men in particular, especially concerning job search (loannides \& Loury, 2004). Otherwise the likely risk factors for experiencing NEET appear to be similar for males and females.

There were however, significant gender differences in the association between parental worklessness and EAO - but only after controlling for all the other variables included in the model. Males growing up with persistently workless parents report higher EAO than females, especially if their parents are educated to degree level, if they live in an urban area, are from an ethnic minority background and have good Key Stage 2 attainment. The findings thus suggest that in specific circumstances, the experience of parental worklessness can impel in particular young males to recognize the value of higher education. Possibly, highly educated parents can motivate their children to achieve in education, independent of their own precarious employment situation (see also Mortimer, Zhang, Hussemann, $\& W u$, this issue). To fully understand the implications of parental worklessness on young males and females, it is thus important to consider the total level of vulnerabilities and different constellations of risk within families.

The study furthermore found significant ethnic differences, with males and females from ethnic minority backgrounds reporting higher levels of EAO than whites, and fewer months being NEET. The study thus confirms previous evidence regarding higher EAOs among ethnic minority children in England (Strand, 2007, 2008). Their higher rates of staying on in full-time education beyond compulsory schooling (Dustmann, Machin \& Schönberg, 2010) have been explained by differences in cultural attitudes towards higher education (Torgerson et al, 2008), and the expectation that better qualifications will reduce the effect of possible future racial discrimination in the labour market (Connor, Tyers, Modood, \& Hillage, 2004). Generally, this study found that high EAO, as well as high previous academic attainment, can act as protective factors, reducing the risk of being longterm NEET.

There are many strengths of this study, among which are the use of a large scale nationallyrepresentative dataset, and the longitudinal design which allows measurement of the duration of worklessness as well as of NEET. As in most longitudinal studies, the analysis is constrained by having to make best use of the available data, their measurement level and timing. For example, parental worklessness and EAOs were measured before the onset of the Great Recession, and the subsequent education and employment transitions just before and during the economic downturn. It was thus not possible to assess how EAOs responded to the economic downturn. However, the data enabled the 
assessment of longer term outcomes associated with parental worklessness and EAO during a period that included a major economic downturn.

Another issue to be addressed is missing data, which might have affected the validity of the results. Although the analytic sample remained largely representative of the population, young people from less privileged family backgrounds were less likely to be included in our analysis. Response bias at the individual level would tend to underestimate the magnitude of effects of social disadvantage, as sample attrition is greatest among cohort members in more deprived circumstances. The problem of missingness in the data was addressed using multiple imputation. Nonetheless, the results might provide a conservative estimate of social inequalities in the sample.

Regarding methodology, this study is one of the first to assess the independent risk effect of parental worklessness on the experience of NEET among males and females. OLS regression models were used to gain a better understanding of how each of the selected variables contributed to the expression of EAO and experience of NEET. Future studies should use Structural Equation Modelling to examine the combined and simultaneous effect of the relevant variables in more detail, and/or Hierarchical Linear Modelling to assess distinct area effects.

In summary, the findings presented here highlight that youth development occurs within a set of interlinked contexts ranging from the macro to the micro level. For a better understanding of young people's experiences in the transition to independent adulthood and the inter-generational transmission of (dis-)advantage, it is important to adopt a developmental-contextual perspective (Schoon, 2006; Vondraceck et al., 1986) and ecological approaches (Bronfrenbrenner, 1986; Elder, 1998) that take into account these multiple influences. The significant role of family socio-demographic factors (in particular low parental education and lack of housing tenure) over and above the experience of parental worklessness in shaping both EAO and experience of NEET highlighted the issue of multiple deprivation, i.e. the accumulation of social and economic disadvantages, as a major factor in reducing the life chances of young people. The findings give only partial support to a policy agenda targeted at workless households per se. They rather point to the need to tackle the wider range of risks that families living in difficult socioeconomic circumstances are facing.

The findings also suggest the manifestation of remarkable resilience among the affected young people. There was a significant interaction between persistent parental worklessness and individual EAO, suggesting that individual EAO can potentially act as a resource factor reducing the risk of negative outcomes for young people growing up in disadvantaged circumstances. Special efforts should thus be directed at young people growing up in families facing multiple economic challenges, especially young males, with the aim of raising their $E A O$, their engagement in education, and removing barriers to employment. This study does, however, only reflect employment experiences of young people between ages 16 to 20, and the observed patterns might not hold for employment related outcomes in the longer run.

Furthermore, the significant role of area characteristics, over and above the experience of parental worklessness and other socio-demographic characteristics, suggests that it matters where young people live, and that area characteristics can affect youth development and adjustment. Previous studies have shown that neighbourhood effects are strongest during early childhood and late adolescence (BrooksGunn, Duncan \& Aber, 1997). This study confirms the importance of area deprivation and points to local opportunities, and potentially also collective socialisation (Ainsworth, 2002; loannides \& Loury, 2004), which influence the type of role models a young person is exposed to outside the home and thereby shape the education and employment transitions of young people. 


\section{Acknowledgements}

Earlier versions of this paper were presented at the 2012 Meeting of the Society for Longitudinal and Life Course Studies, Paris. The study is supported by Grant Numbers ES/J019658/1 and ES/J019135/1 from the British Economic and Social Research Council (ESRC) for the Centre for Learning and Life-chances in the Knowledge Economies (LLAKES, Phase II) and the ESRC workshop series on Young People and the Great Recession. The content is solely the responsibility of the author and may not represent the views of the sponsors.

\section{References}

Ainsworth, J. W. (2002). Why does it take a village? The mediation of neighborhood effects on educational achievement. Social Forces, 81, 117-152. http://dx.doi.org/10.1353/sof.2002.0038

Ashton, D., \& Bynner, J. (2011). Labour market, employment and skills. In M. E. J. Wadsworth \& J. Bynner (Eds.), A companion to life course studies. The social and historical context of the British birth cohort studies (pp. 122-147). London: Routledge.

Beal, S. J., \& Crockett, L. J. (2010). Adolescents' occupational and educational aspirations and expectations: Links to high school activities and adult educational attainment. Developmental Psychology, 46, 258-265. http://dx.doi.org/10.1037/a0017416

Berthoud, R. (2011) Trends in the employment of disabled people in Britain. Vol. ISER Working Paper Series, 2011-03: Institute for Social and Economic Research, University of Essex.

Bradley, R. H., \& Corwyn, R. F. (2002). Socioeconomic status and child development. Annual Review of Psychology, 53, 371-399. http://dx.doi.org/10.1146/annurev.psych.53.100901.135233

Bradshaw, J., \& Mayhew, E. (Eds.). (2005). The Well-being of Children in the United Kingdom. London: Save the Children.

Bronfenbrenner, U. (1986). Ecology of the family as a context for human development: Research perspectives Developmental Psychology 22, 723-742. http://dx.doi.org/10.1037/0012-1649.22.6.723

Brooks-Gunn, J., Duncan, G. J., \& Aber, L. (1997). Neighborhood Poverty: Context and Consequences for Children. New York: Russel Sage Foundation.

Coelli, M. B., Green, D. A., \& Warburton, W. P. (2007). Breaking the cycle? The effect of education on welfare receipt among children of welfare recipients. Journal of Public Economics, 91, 1369-1398.

Collingwood, A., Cheshire, H., Nicolaas, G., D'Souza, J., Ross, A., Hall, J., Armstrong, C., Prosser, A., Green, R.,Collins, D.,Gray, M.,McNaughton Nicolls, C. . (2010). A review of the Longitudinal Study of Young People in England (LSYPE): Department for Education, Research Report DFE-RR048. https://www.gov.uk/government/uploads/system/uploads/attachment data/file/181703/DFERR048.pdf

Connor, H., Tyers, C., Modood, T. and Hillage, J. (2004), Why the Difference: A closer look at ethnic minority students and graduates. Research report No. 552. London: DfES.

Crawford, C., Duckworth, K., Vignoles, A., \& Wyness, G. (2011). Young people's education and labour market choices aged 16 to 19. London: Centre for Analysis of Youth Transitions. http://www.ifs.org.uk/publications/5962o.

Dustmann, C., Machin, S., \& Schönberg, U. (2010). Ethnicity and educational achievement in compulsory schooling. Economic Journal, 120, F272-F297.

Elder, G. H. (1998). The life course as developmental theory. Child Development, 69, 1-12.

Engle, P. L., \& Black, M. M. (2008). The Effect of Poverty on Child Development and Educational Outcomes. Ann NY Acad Sci, 1136, 243-256.

Ermisch, J., Francesconi, M., \& Pevalin, D. J. (2004). Parental partnership and joblessness in childhood and their influence on young people's outcomes. Journal of the Royal Statistical Society Series a-Statistics in Society, 167, 69-101.

Erikson, R. (1984). Social class of men, women and families. Sociology, 18, 500-514. http://dx.doi.org/10.1177/0038038584018004003

European Parliament. (2013). The advantages of a gender-sensitive approach to tackle youth unemployment. European Parliament. Policy Department. EST92550.pdfo.

European Commission (2014) Eurostat, 2012. http://epp.eurostat.ec.europa.eu/tgm/table.do?tab=table\&init=1\&plugin=1\&language=en \&pcode=tps $\underline{00181}$ 
Gottschalk, P. (1996). Is the correlation in welfare participation across generations spurious? Journal of Public Economics, 63, 1-25. http://dx.doi.org/10.1016/S0047-2727(96)01585-X

Gregg, P., \& Wadsworth, J. (2001). Everything you ever wanted to know about measuring worklessness and polarization at the household level but were afraid to ask. Oxford Bulletin of Economics and Statistics, 63, 777-806. http://dx.doi.org/10.1111/1468-0084.63.spe1.9

Gregg, P., Harkness, S., \& Machin, S. (1999). Poor Kids: Trends in Child Poverty in Britain, 1968-96 Fiscal Studies, 20, 163-187. http://dx.doi.org/10.1111/j.1475-5890.1999.tb00009.x

Gregg, P., \& Wadsworth, J. (2008). Two sides to every story: Measuring polarization and inequality in the distribution of work. Journal of the Royal Statistical Society Series A-Statistics in Society, 171, 857-875.

Gutman, L. M., Schoon, I., \& Sabates, R. (2012). Uncertain aspirations for continuing in education: Antecedents and associated outcomes. Developmental Psychology, 48, 1707-1718. http://dx.doi.org/10.1037/a0026547

Harkonen, J. (2011). Children and dual worklessness in Europe: A comparison of nine countries. European Journal of Population-Revue Europeenne De Demographie, 27, 217-241. http://dx.doi.org/10.1007/s10680-011-9232-3

Haveman, R. H., \& Wolfe, B. (1994). Succeeding generations: On the effects of investments in children. New York: Russell Sage Foundation.

lacovou, M., \& Berthoud, R. (2000). Parents and employment. An analysis of low-income families in the British Household Panel Survey. London: Stationary Office.

Ioannides, Y. \& Loury, L. (2004). Job information networks, neighbourhood effects and inequality. Journal of Economic Literature, 42, 1056-93. http://dx.doi.org/10.1257/0022051043004595

Jencks, C., \& Mayer, S. E. (1990). The social consequences of growing up in a poor neighbourhood. In L. E. J. Lynn \& M. G. H. McGeary (Eds.), Inner-city poverty in the United States (pp. 111-187). Washington, DC: National Academy Press.

Jenkins, S., Brandolini, A., Micklewright, J., \& Nolan, B. (2013). The great recession and the distribution of household income. Oxford: Oxford University Press.

Johnson, M. K., \& Reynolds, J. R. (2013). Educational expectation trajectories and attainment in the transition to adulthood. Social Science Research, 42, 818-835. http://dx.doi.org/10.1016/i.ssresearch.2012.12.003

Johnson, P., \& Reed, H. (1996). Intergenerational mobility among the rich and poor: Results from the National Child Development Study. Oxford Review of Economic Policy, 12, 127-143. http://dx.doi.org/10.1093/oxrep/12.1.127

Kerckhoff, A. C. (1993). Diverging pathways: Social structure and career deflections. Cambridge: Cambridge University Press.

Kerckhoff, A. C. (2001). Education and social stratification processes in comparative perspective. Sociology of Education, 74, 3-18. http://dx.doi.org/10.2307/2673250

Leventhal, T., \& Brooks-Gunn, J. (2003). Children and youth in neighborhood contexts. Current Directions in Psychological Science, 12, 27-31.

Macmillan, L. (2010). The intergenerational transmission of worklessness in the UK. Bristol: The Centre for Market and Public Organisation (CMPU).

Macmillan, L. 2011). Measuring the intergenerational correlation of worklessness Bristol: Bristol Institute of Public Affairs, University of Bristol, Working Paper No. 11/278. http://www.bristol.ac.uk/cmpo/publications/papers/2011/wp278.pdf

Macmillan, L. (2014). Intergenerational worklessness in the UK and the role of local labour markets. Oxford Economic Papers Advance Access. http://oep.oxfordjournals.org/content/early/2014/02/05/oep.gpt046.short?rss=1

Marjoribanks, K. (1989). Environments, adolescents' aspirations and young adults' status attainment. Educational Studies, 15, 155-164. http://dx.doi.org/10.1080/0305569890150206

McLanahan, S. (1997). Parent absence or poverty: Which matters more? In G. J. Duncan \& J. Brooks-Gunn (Eds.), Consequences of growing up poor (pp. 35-48). New York: Russell Sage Foundation.

McLanahan, S. (2004). Diverging destinies: How children are faring under the second demographic transition. Demography, 41, 607-627. http://dx.doi.org/10.1353/dem.2004.0033

McLanahan, S., \& Sandefur, G. (1994). Growing up with a single parent: What hurts, what helps? Cambridge, MA: Harvard University Press.

Mello, Z. R. (2008). Gender variation in developmental trajectories of educational and occupational expectations and attainment from adolescence to adulthood. Developmental Psychology, 44, 1069-1080.

http://dx.doi.org/10.1037/0012-1649.44.4.1069 
Mortimer, J.T., Zhang, L., Hussemann, J., \& Wu, C-Y. (2014). Parental economic hardship and children's achievement orientations. Longitudinal and Life Course Studies, 5, 105-128. http://dx.doi.org/10.14301/llcs.v5i2.271

Murry, V. M., Berkel, C., Gaylord-Harden, N. K., Copeland-Linder, N., \& Nation, M. (2011). Neighborhood Poverty and Adolescent Development. [Article]. Journal of Research on Adolescence, 21, 114-128.

ONS. (2011). Working and workless households. Office for National Statistics. Statistical Bulletin http://www.ons.gov.uk/ons/dcp171778 229480.pdf.

ONS. (2012). Characteristics of young unemployed people: Office for National Statistics. http://www.ons.gov.uk/ons/dcp171776 256894.pdf

O'Neill, D., \& Sweetman, O. (1998). Intergenerational mobility in Britain: Evidence from unemployment patterns. Oxford Bulletin of Economics and Statistics, 60, 431-449. http://dx.doi.org/10.1111/1468$\underline{0084.00108}$

Pemberton, S. (2008). Tackling the NEET generation and the ability of policy to generate a 'NEET' solution evidence from the UK. Environment and Planning C-Government and Policy, 26, 243-259. http://dx.doi.org/10.1068/c0654

Platt, L. (2010). Ten year transitions in children's experience of living in a workless household: Variations by ethnic group. Population Trends, 139, 70-90. http://dx.doi.org/10.1057/pt.2010.6

Reynolds, J. R., \& Burge, S. W. (2008). Educational expectations and the rise in women's post-secondary attainments. Social Science Research, 37, 485-499. http://dx.doi.org/10.1016/i.ssresearch.2007.09.002

Reynolds, J. R., \& Pemberton, J. (2001). Rising college expectations among youth in the United States - a comparison of the 1979 and 1997. US National Longitudinal Study of Youth. Journal of Human Resources, 36, 703-726. http://dx.doi.org/10.2307/3069639

Royston, P., Carlin, J. B., \& White, R. R. (2009). Multiple imputation of missing values: New features for mim. Stata Journal, 9, 252-264.

Rubin, D. B. (1996). Multiple imputation after 18+ years. Journal of the American Statistical Association, 91, 473489. http://dx.doi.org/10.1080/01621459.1996.10476908

Rutter, M. (1981). Stress, coping and development - some issues and some questions. Journal of Child Psychology and Psychiatry and Allied Disciplines, 22, 323-356. http://dx.doi.org/10.1111/i.14697610.1981.tb00560.x

Rutter, M. (2009). Understanding and testing risk mechanisms for mental disorders. Journal of Child Psychology and Psychiatry, 50, 44-52. http://dx.doi.org/10.1111/j.1469-7610.2008.01976.x

Schneider, B., \& Stevenson, D. (1999). The ambitious generation: America's teenagers, motivated but directionless. New Haven: Yale University Press.

Schoon, I. (2006). Risk and resilience: Adaptations in changing times. Cambridge: Cambridge University Press. http://dx.doi.org/10.1017/CBO9780511490132

Schoon, I. (2010). Planning for the future: Changing education expectations in three British cohorts. Historical Social Research-Historische Sozialforschung, 35, 99-119.

Schoon, I., Barnes, M., Parsons, S., Brown, V., Ross, A., \& Vignoles, A. (2012). Intergenerational transmission of worklessness: Evidence from the millennium cohort and the longitudinal study of young people in england. Department for Education. DFE-RR-234.

https://www.education.gov.uk/publications/eOrderingDownload/DFE-RR234.pdf

Schoon, I., Martin, P., \& Ross, A. (2007). Career transitions in times of social change. His and her story. Journal of Vocational Behavior, 70, 78-96. http://dx.doi.org/10.1016/i.jvb.2006.04.009

Schoon, I., \& Parsons, S. (2002). Teenage aspirations for future careers and occupational outcomes. Journal of Vocational Behavior, 60, 262-288. http://dx.doi.org/10.1006/jvbe.2001.1867

Sewell, W. H., Haller, A. O., \& Ohlendorf, G. W. (1970). The educational and early occupational status attainment process: Replication and revision. American Sociological Review, 35, 1014-1027. http://dx.doi.org/10.2307/2093379

Sewell, W. H., \& Hauser, R. M. (1975). Education, occupation, and earnings: Achievement in the early career. New York: Academic Press.

Sewell, W. H., Hauser, R. M., \& Wolf, W. C. (1980). Sex, schooling, and occupational status. The American Journal of Sociology, 86, 551-583. http://dx.doi.org/10.1086/227281

Shildrick, T., MacDonald, R., Furlong, A., Roden, J., \& Crow, R. (2012). Are 'cultures of worklessness' passed down the generations? York: Joseph Rowntree Foundation. http://www.jrf.org.uk/sites/files/irf/worklessness-families-employment-full.pdf

Strand, S. (2007). Minority ethnic pupils in the Longitudinal Study of Young People in England (LSYPE). London: Department for Children, Schools and Families (DCSF). Research Report No RRO02. 
http://webarchive.nationalarchives.gov.uk/20130401151715/https://www.education.gov.uk/publicati ons/eOrderingDownload/DCSF-RR002.pdf

Strand, S. (2008), Minority Ethnic Pupils in the Longitudinal Study of Young People in England. Report DCSFRR029. London: Department for Children, Schools and Families.

Such, E., \& Walker, R. (2002). Falling behind? Research on transmitted deprivation Benefits, 35, 185-192.

Torgerson, C., Gorard, S., Low, G., Ainsworth, H., See, B. H. and Wright, K. (2008), What are the factors that promote high post-16 participation of many minority ethnic groups?: A focused review of the UK-based aspirations literature. Institute of Education, Social Science Research Unit, University of London. Evidence for Policy and Practice Information and Co-ordinating Centre . http://eppi.ioe.ac.uk/cms/Default.aspx?tabid=2386

Vondracek, F. W. (1998). Career development: A lifespan perspective. International Journal of Behavioral Development, 22, 1-6. http://dx.doi.org/10.1080/016502598384487

Vondraceck, F. W., Lerner, R. M., \& Schulenberg, J. E. (1986). Career development: A life-span developmental approach. Hillsdale, NJ: Erlbaum.

Vuolo, M., Staff, J., \& Mortimer, J. T. (2012). Weathering the great recession: Psychological and behavioral trajectories in the transition from school to work. Developmental Psychology, 48, 1759-1773. http://dx.doi.org/10.1037/a0026047

Webster, D. (2000). The geographical concentration of labour market disadvantage. Oxford Review of Economic Policy, 16, 114-128. http://dx.doi.org/10.1093/oxrep/16.1.114

\section{Endnotes}

' General Certificate of Secondary Education (GCSE): a public examination in specified subjects given at the end of key stage 4 for 16 year-olds in England which is part of the National Qualifications Framework. Candidates receive a grade for each subject that they have sat. The pass grades, from highest to lowest, are: $A^{*}$ (pronounced 'A-star'), $A, B, C, D, E, F$ and $G$. Grade $U$ (ungraded/unclassified) is issued when students have not achieved the minimum standard to achieve a pass grade; the subject is then not included on their final certificate. A GCSE at grades D-G is a Level 1 qualification, while a GCSE at grades $A^{*}-C$ is a Level 2 qualification. As one would expect, GCSEs at $A^{*}-C$ (Level 2) are much more desirable and insisted on by many employers and educational institutions. Level 1 qualifications are required to advance to Level 2 qualifications. Likewise, Level 2 qualifications are required to advance to Level 3 qualifications.

ii A Key Stage is a stage of the state education system in England, Wales and Northern Ireland. Key Stage 2 reflects attainment at the later stage of primary education, often known as junior schools. 
